\title{
AMAR
}

AMAR (Andalas Management Review)

Vol. 4, No. 2 (2020) 46-59

The Management Institute, Faculty of Economics, Universitas Andalas

ISSN (Print) 2476-9282 | ISSN (Online) 2548-155X

\section{Pengaruh Pendapatan Asli Daerah, Dana Alokasi Umum, Rasio Efektivitas dan Rasio Kemandirian Terhadap Indeks Pembangunan Manusia}

\author{
Siti Munfaridaa, Eko Priyojadmiko ${ }^{\mathrm{b}}$ \\ ${ }^{a}$ Ekonomi Syariah, FEBI, UIN Sunan Kalijaga Yogyakarta, smunfarida@gmail.com \\ ${ }^{b}$ Perbankan Syariah, STAI Muhammadiyah Tulungagung, jadmiko.uinsuka@gmail.com
}

\begin{abstract}
The aim of this research to analyze the effect of original local government revenue, Dana Alokasi Umum (DAU), effectivity ratio and independence ratio on the Human Development Index (HDI).Quantitative research methode was used in this reasearch. The population are 35 Kabupaten/Kota at Central Java Province in 2015-2017. With purposive sampling technique was taken as many as 24 of the samples that can be analyzed. The data analysis methode using panel data regression analysis. And the data processed using Eviews 10. The result showed that, first original local government revenue have positive signifficant influence on human development index. Second, dana alokasi umum have p positive signifficant influence on human development index. Independence ratio doesn't have signifficant effected on human development index. Effectivity ratio doesn't have signifficant effected on HDI.
\end{abstract}

Keyword: Original Local Government Revenue, Dana Alokasi Umum, Independence Ratio, Effectivity Ratio, Human Development Index, finnacial local government performance.

\section{PENDAHULUAN}

UNDP atau United Development Programme pertama kali menyampaikan konsep indeks pembangunan manusia (IPM) melalui laporan tahunan dengan judul Human Development Report pada tahu 1990. Untuk pembangunan manusia sendiri diartikan sebagai proses perluasan pilihan bagi penduduk atau disebut "process of enlarging people's choice". Indeks Pembangunan Manusia (IPM) merupakan indikator yang digunakan untuk mengukur tingkat pencapaian pembangunan manusia agar hidup secara lebih berkualitas, baik dilihat dari segi kesehatan, pendidikan maupun perekonomiannya. IPM menjelaskan bagaimana hasil pembangunan dapat diakses oleh seluruh penduduk seperti terjaminnya perolehan pendapatan, terjaminnya faisilitas kesehatan, terjaminnya pendidikan dan sebagainya (Booklet IPM BPS, 2014).

Berdsarkan laporan UNDP pada tahun 2017, Indonesia mengalami penurunan satu peringkat menjadi peringkat 116 dari 189 negara, meskipun nilai dari IPM naik. Indonesia 
masuk dalam kategori high human development, di bawah negara tetangga seperti Filipina, Malaysia, Brunei Darussalam, Thailand dan Singapura (UNDP, 2018). Sehingga, IPM di Indonesia masih harus terus ditingkatkan. Pembangunan nasional tidak dapat dilakukan secara menyeluruh jika pengelolaan kewenangannya hanya dari pemerintah pusat saja, mengingat luasnya Indonesia. Maka pembangunan di daerah juga diperlukan khususnya pembangunan manusia, sehingga kesenjangan antara daerah dan pusat dapat diatasi. Jawa Tengah menjadi salah satu wilayah di Indonesia yang nilai IPM cukup rendah jika dibandingkan dengan provinsi-provinsi lainnya di Pulau Jawa.

Tabel 1.

Daftar nilai IPM Provinsi di Pulau Jawa

\begin{tabular}{|c|c|c|c|c|c|c|c|c|}
\hline Provinsi & 2010 & 2011 & 2012 & 2013 & 2014 & 2015 & 2016 & 2017 \\
\hline DKI Jakarta & 76.31 & 76.98 & 77.53 & 78.08 & 78.39 & 78.99 & 79.60 & 80.06 \\
\hline Jawa Barat & 66.15 & 66.67 & 67.32 & 68.25 & 68.80 & 69.5 & 70.05 & 70.69 \\
\hline Jawa Tengah & 66.08 & 66.64 & 67.21 & 68.02 & 68.78 & 69.49 & 69.98 & 70.52 \\
\hline DIY & 75.37 & 75.93 & 76.15 & 76.44 & 76.81 & 77.59 & 78.38 & 78.89 \\
\hline Jawa Timur & 65.36 & 66.06 & 66.74 & 67.55 & 68.14 & 68.95 & 69.74 & 70.27 \\
\hline Banten & 67.54 & 68.22 & 68.92 & 69.47 & 69.89 & 70.27 & 70.96 & 71.42 \\
\hline
\end{tabular}

Berdasakan data di atas, presentasi nilai IPM Jawa Tengah pada tahun 2010-2017 berada pada posisi dua terbawah diantara 6 provinsi di Pulau Jawa. Sehingga tergolong cukup rendah. Untuk dapat menjalankan misi pembangunan nasional di masing-masing daerah, diperlukan sumber dana yang cukup. Pada UU No 32 Tahun 2004 dan UU No 33 Tahun 2004 telah dijelaskan beberapa sumber dana yang dapat digunakan dalam segala aktivitas kegiatan daerah dalam rangka menjalankan desentralisasi.

Desentralisasi Fiskal membuat pemerintah daerah harus pintar mengalokasikan dana dari APBD tidak hanya pada sektor utama, namun juga pada sektor pendukung dalam meningkatkan kesejahteraan masyarakat. Pendapatan Asli Daerah (PAD) menjadi salah satu sumber utama pendanaan dalam membiayai belanja daerah. PAD diperoleh dari pendapatan yang bersumber dari potensi daerah sendiri seperti misalnya pajak daerah, retribusi daerah, pendapatan hasil pengelolaan daerah yang dipisahkan, dan pendapatan asli daerah lainnya yang sah. Diharapkan dengan tingginya PAD sebagai sumber pendanaan mandiri dapat digunakan untuk alokasi pembiayaan dalam rangka peningkatan pelayanan kepada masyarakat seperti infrastruktur dan kesehatan, yang merupakan tujuan dari pembangunan manusia, sehingga indeks pembangunan manusia juga bisa meningkat pada daerah tersebut ( Sarkoro dan Zulfikar, 2016). 
Dalam mencegah terjadinya ketimpangan fiskal karena setiap daerah mempunyai potensi yang berbeda maka berdasarkan UU No. 32 tahun 2004 yang merujuk adanya sumber dana lain yang bisa dimanfaatkan untuk aktivitas pembangunan daerah yakni menggunakan dana perimbangan, terdiri dari Dana Alokasi Umum (DAU), Dana Alokasi Khusus (DAK) dan Dana Bagi Hasil (DBH), serta pendapatan lainnya yang sah. Berdasarkan PP No.55/2005, DAU merupakan dana yang dialokasikan kepada daerah dari APBN untuk tujuan mewujudkan pemerataan kemampuan keuangan antar daerah dalam pendanaan kegiatan daerah dalam rangka desentralisasi. Seperti tujuan awal dari DAU untuk memenuhi tujuan desentralisasi dan mengatasi kesenjangan fiskal. Maka diharapkan dengan adanya alokasi DAU dapat membantu pemerintah daerah dalam pemenuhan kebutuhan daerahnya sehingga dapat meningkatkan kualitas dari pembangunan manusia pada daerah tersebut (Sarkoro dan Zulfikar, 2016). Melihat desentralisasi fiskal sudah berjalan dengan baik atau belum dapat mengunakan indikator kinerja keuangan. Untuk melihat bagaimana kinerja pemerintah daerah dalam mengelola APBD terhadap segala kegiatan daerah tersebut dapat dilakukan analisis rasio pada keuangan daerah tersebut (Halim, 2007:231)

Penelitian mengenai kinerja keuangan yang dihitung melalui rasio-rasio keuangan terhadap IPM sebelumnya oleh Dwiyandari dan Badera (2018) menunjukkan hasil bahwa rasio kemandirian memiliki pengaruh positif terhadap IPM. Penelitian dari Suryaningsih, et al (2015) dimana hasilnya menunjukkan bahwa rasio kemandirian pada keuangan daerah, rasio efektivitas pada keuangan daerah serta upaya pemungutan PAD berpengaruh positif terhadap kesejahteraan masyarakat Kabupaten/Kota di Provinsi Bali tahun 2001-2011. Dan hasil penelitian dari Anggraini (2015) hasilnya menunjukkan rasio kemandirian memiliki pengaruh terhadap IPM. Rasio keuangan dalam penelitian ini terdiri dari rasio kemandirian dan rasio efektivitas. Rasio kemandirian dilakukan dengan membandingkan total PAD yang diperoleh dengan jumlah bantuan dari pemerintah ataupun pinjaman. Sedangkan rasio efektivitas dilakukan dengan membagi total realisasi penerimaan PAD dengan target penerimaan PAD yang ditetapkan. Kedua rasio ini dipilih karena dirasa masih terdapat adanya perbedaan dari hasil penelitian. Hal tersebut menarik bagi peneliti untuk dapat meneliti kedua rasio ini. Dengan bagusnya kinerja keuangan suatu daerah diharapkan pemerintah daerah dapat mengelola dan mengalokasikan APBD untuk meningkatkan kesejahteraan masyarakat sehingga juga dapat meningkatkan IPM Kabupaten/Kota.

Pembeda dari penelitian ini dengan penelitian-penelitian sebelumnya dikarenakan adanya penggabungan penilaian kinerja keuangan daerah dengan anggaran keuangan 
daerah, dimana pada beberapa penelitian terdahulu hanya meneliti PAD dan DAU secara terpisah dengan kinerja keuangan terhadap IPM. Sehingga peneliti tertarik untuk melakukan penelitian ini, kareana dapat diketahui apakah anggaran yang diperoleh telah digunakan secara bijak untuk mencapai tujuan desentralisasi fiskal dan otonomi daerah. Berdasarkan beberapa penjelasan diatas peneliti tertarik meneliti bagaimana "Pengaruh Pendapatan Asli Daerah, Dana Alokasi Umum, Rasio Efektivitas dan Rasio Kemandirian terhadap Indeks Pembangunan Manusia di Provinsi Jawa Tengah Tahun 2015-2017".

Pendapatan Asli Daerah merupakan pendapatan yang diterima pemerintah daerah atas dasar peraturan daerah yang tidak melanggar perundang-undangan, bertujuan memberikan kewenangan terhadap pemerintah daerah dalam mendanai kegiatan pelaksanaan otonomi daerah memanfaatkan potensi yang ada dalam mewujudkan desentralisasi (UU No. 33 Tahun 2004). Pada UU No. 23 tahun 2014, PAD merupakan parameter keuangan daerah yang dapat digunakan untuk menjadi tolak ukur kemandirian daerah dalam pembiayaan pembangunan di daerah tersebut. Dana Alokasi Umum termasuk dana perimbangan yang dihibahkan untuk daerah dari APBN, untuk menghindari adanya kesenjangan fiskal antar daerah dalam pemenuhan kebutuhan daerah untuk kegiatan desentralisasi. Minimal jumlah DAU adalah 26\% atas pendapatan dalam negeri neto dalam APBN. Desentralisasi Fiskal bertujuan diberlakukannya desentralisasi fiskal adalah membuat sistem publik yang mampu membuat penyediaan barang dan jasa publik lokal secara efektif dan efisien, namun makroekonomi tetap terjaga (Rahmawati, 2008:27). UU No. 25 Tahun 1999 yang kemudian direvisi menjadi UU No 33 Tahun 2004, terkait adanya pembaruan terhadap isu otonomi dan desentralisasi.

Rasio kemandirian merupakan rasio yang menggambarkan besaran kemampuan daerah dalam mendanai kegiatan daerah, pembangunan, serta pelayanan kepada masyarakat secara mandiri yakni dengan memanfaatkan dana Pendapatan Asli Daerah. Di mana dana tersebut diperoleh dari hasil pengelolaan sumber daya dan potensi dari daerah tersebut, misalnya dari pajak dan retribusi. Rumus dari rasio ini adalah:

$$
R K=\frac{P A D}{\text { Bantuan pusat atau provinsi dan pinjaman }}
$$

Kemandirian suatu daerah dapat dikategorikan sebagai berikut:

Tabel 2.

Kategori Kemandirian

Kemampuan Keuangan Persentase Kemandirian 


\begin{tabular}{ll}
\hline Sangat Rendah & 0 sampai $25 \%$ \\
\hline Rendah & $25 \%$ sampai $50 \%$ \\
\hline Sedang & $50 \%$ sampai $75 \%$ \\
\hline Tinggi & $75 \%$ sampai $100 \%$ \\
\hline Sumber: Halim, 2002 &
\end{tabular}

Rasio Efektifitas merupakan rasio yang memberikan gambaran akan kemampuan daerah dalam merealisasikan APBD yang telah direncanakan dan membandingkannya dengan target pencapaiannya (Halim 2002). Rumus dari rasio ini adalah:

$$
R E=\frac{\text { Realisasi penerimaan } P A D}{\text { Target penerimaan PAD berdasarkan potensinyata daerah }}
$$

Kategori dari kefektivan dari suatu daerah telah dijealaskan dalam Kepmendagri No 690.900-327 tahun 1996 (Dwindra, 2008). Kategori tersebut adalah:

Tabel 3.

Kategori Efektif

\begin{tabular}{ll}
\hline Kemampuan Keuangan & Rasio Efektivitas \% \\
\hline Sangat efektif & Lebih dari 100 \\
\hline Efektif & 90 sampai 100 \\
\hline Cukup efektif & 80 sampai 90 \\
\hline Kurang Efektif & 60 sampai 80 \\
\hline Tidak Efektif & 0 sampai 60 \\
\hline Sumber: Kepmendagri No. 690.900-327
\end{tabular}

Indeks Pembangunan Manusia merupakan gambaran bagaimana penduduk dalam mengakses hasil pembangunan seperti dalam memperoleh pendapatan, kesehatan, pendidikan, dan sebagainya. Pembangunan manusia didefinisikan sebagai "process of enlarging people's choice" (Booklet IPM BPS, 2014). IPM menjadi tolak ukur penting penting dalam menilai kesuksesan pembangunan kualitas hidup masyarakat. IPM terdiri dari tiga dimensi dasar yakni umur panjang dan hidup sehat, pengetahuan dan standar hidup layak (Booklet IPM BPS, 2014). Menurut BPS, IPM dapat dikelompokkan ke dalam empat kategori, yakni:

Tabel 4.

Kategori IPM

\begin{tabular}{ll}
\hline Rendah & Kurang dari 60 \\
\hline Sedang & Antara 60 sampai 69 \\
\hline Tinggi & Antara 70 sampai 79 \\
\hline Sangat Tinggi & 80 ke atas \\
\hline
\end{tabular}


Sumber : BPS (2014)

IPM dirumuskan sebagai berikut:

$$
I P M=\sqrt[s]{I_{\text {kesehatan }} x I_{\text {pendidikan }} x I_{\text {pengeluaran }}} \times 100
$$

\subsection{Hubungan antara PAD terhadap IPM}

Pendapatan asli daerah merupakan pendapatan dari kemampuan daerah dalam memanfaatkan potensi daerah yang ada untuk dapat dimanfaatkan ke dalam kegiatan ekonomi yang dapat memghasilkan aliran dana untuk pembangunan daerah yang berkelanjutan. PAD sebagai sumber pendanaan mandiri diharapkan dapat digunakan sebagai sumber pendanaan dalam upaya peningkatan kualitas pelayanan kepada masyarakat seperti infrastruktur dan kesehatan, sehingga dapat meningkatkan indeks pembangunan manusia (Sarkoro dan Zulfikar, 2016). Sehingga dari uraian di atas dapat diambil hipotesis sebagai berikut:

$\mathrm{H}_{1} \quad$ : Pendapatan asli daerah berpengaruh secara signifikan positif terhadap indeks pembangunan manusia

\subsection{Hubungan DAU terhadap IPM}

Dana alokasi umum meruppakan dana yang diberikan oleh pemerintah berdasarkan kemampuan fiskal masing-masing daerah dalam upaya pemerataan pembangunan daerah dengan mengurangi terjadinya kemungkinan kesenjangan fiskal antar daerah. Pemerintah diharapkan dapat mengalokasi DAU dengan baik dan diharapkan dana tersebut dapat membantu dalam pemenuhan kebutuhan daerah sehingga dapat meningkatkan kualitas pembangunan manusia pada daerah tersebut sesuai dengan tuntutan desentralisasi (Sarkoro dan Zulfikar, 2016). Dari uraian di atas maka dapat diambil hipotesis sebagai berikut:

$\mathrm{H}_{2}$ : Dana alokasi umum berpengaruh signifikan positif terhadap indeks pembangunan manusia.

\subsection{Hubungan Rasio Efektivitas terhadap IPM}

Rasio efektivitas merupakan gambaran mengenai bagaimana kemampuan daerah dalam merealisasikan APBD yang telah direncanakan dan dibandingkan dengan target yang telah ditetapkan berdasarkan potensi nyata daerah (Halim 2012). Rasio ini 
menggambarkan kemampuan suatu daerah dalam menjalankan tugasnya secara efektif dalam menghasilkan penerimaan sesuai dengan apa yang telah ditargetkan. Tingginya efektivitas dalam penerimaan PAD diharapkan pemerintah daerah juga dapat memanfaatkannya untuk menjalankan tugasnya memberikan pelayanan kepada masyarakat secara maksimal, khususnyadalam sektor inti yang dapat berakibat pada kesejahteraan penduduk. Sehingga dapat pula meningkatkan indeks pembangunan manusia. Sehingga diperoleh hipotesis sebagai berikut:

$\mathrm{H}_{3}$ : Rasio Efektivitas berpengaruh signifikan positif terhadap Indeks Pembangunan Manusia.

\subsection{Hubungan Rasio Kemandirian terhadap IPM}

Rasio kemandirian merupakan rasio yang menggambarkan besarnya kemampuan daerah dalam pembiayaan kegiatan daerah, pembangunan, dan pelayanan kepada masyarakat secara mandiri yakni dengan memanfaatkan dana Pendapatan Asli Daerah. Di mana dana tersebut diperoleh dari hasil pengelolaan sumber daya dan potensi dari daerah tersebut, misalnya dari pajak dan retribusi. Diberlakukannya desentralisasi fiskal membuat pemerintah daerah dituntut untuk dapat mengelola dan mengurus sendiri segala kegiatan pemerintahannya. Tingginya kemandirian keuangan suatu daerah maka daerah tersebut mempunyai kebebasan dalam memanfaaatkan dana tersebut untuk menjalankan tugasnya dalam melayani masyarakat secara maksimal sesuai dengan perundang-undangan, seperti melakukan pembangunan fasilitas kesehatan, pendidikan dan tercapainya harga komoditas yang stabil. Dengan meningkatnya layanan masyarakat maka diharapkan meningkat pula kesejahteraan penduduk yang dapat pula meningkatkan indeks pembangunan manusia. Sehingga diperoleh hipotesis sebagai berikut

$\mathrm{H}_{4}$ : Rasio Kemandirian berpengaruh signifikan positif terhadap Indeks Pembangunan Manusia

\section{METODE}

Variabel penelitian terdiri dari variabel independen diantaranya Pendapatan Asli Daerah (PAD), Dana Alokasi Umum (DAU), Rasio Kemandirian dan Rasio Efektivitas. Dan variabel dependen yaitu Indeks Pembangunan Manusia Kabupaten/Kota di Provinsi Jawa Tengah tahun 2015-2017. Populasi merupakan sekelompok orang, kejadian atau halhal yang memiliki karakteristik tertentu (Indriantoro dan Supomi, 2002:115). Pada 
penelitian ini populasinya adalah keseluruhan dari Kabupaten/Kota di Provinsi Jawa Tengah yang meliputi 35 Kabuapten/Kota yang ada di Provinsi Jawa Tengah. Metode pengambilan sampel menggunakan metode purposive sampling, di mana hanya sampel yang memenuhi kriteria yang dapat digunakan. Kriteria yang digunakan dalam pengambilan sampel ini diantaranya terpenuhinya keseluruhan data yang diperlukan dalam penelitian seperti data IPM, data PAD baik realisasi maupun target, data DAU, data bantuan dari pemerintah pusat dan pinjaman, serta lolos pengujian outlier. Sehingga diperoleh 24 sampel yang dapat dilakukan analisis statistik.

Tabel 5.

Pengambilan Sampel

\begin{tabular}{cl}
\hline Jumlah Populasi & 35 Kabupaten/Kota \\
\hline Data terpenuhi & 35 Kabupaten/Kota \\
\hline Lolos Uji Outlier & 24 Kabupaten/Kota \\
\hline Sampel yang tidak lolos & 11 Kabupaten/Kota \\
\hline Sumber:Data Diolah, 2019. &
\end{tabular}

Dari beberapa sampel diatas, maka diambil sebanyak 24 Kabupaten yang akan dijadikan sebagai sampel penelitian, adapun beberapa Kabupaten tersebut dijelaskan pada Tabel 6 berikut ini:

Tabel 6

Data dari Kabupaten/Kota yang Digunakan

\begin{tabular}{clcl}
\hline No & Kabupaten/Kota & No & \multicolumn{1}{c}{ Kabupaten/Kota } \\
\hline 1 & Banjarnegara & 13 & Pekalongan \\
\hline 2 & Banyumas & 14 & Purbalingga \\
\hline 3 & Blora & 15 & Purworejo \\
\hline 4 & Cilacap & 16 & Rembang \\
\hline 5 & Demak & 17 & Semarang \\
\hline 6 & Grobogan & 18 & Sukoharjo \\
\hline 7 & Jepara & 19 & Temanggung \\
\hline 8 & Kebumen & 20 & Wonogiri \\
\hline 9 & Kendal & 21 & Wonosobo \\
\hline 10 & Kudus & 22 & Kota Magelang \\
\hline 11 & Magelang & 23 & Kota Pekalongan \\
\hline 12 & Pati & 24 & Kota Semarang \\
\hline Sumber: Data Diolah, 2019 & &
\end{tabular}

Data yang digunakan berupa data sekunder dimana data tersebut diperoleh secara tidak langsung melalui media perantara (diperoleh dan dicatat pihak lain). Data IPM diperoleh dari situs Badan Pusat Statistik (BPS), dan untuk data PAD, DAU, Rasio Efektivitas dan Rasio Kemandirian diperoleh dari situs http://www.djpk.kemenkeu.go.id. Metode analisis yang digunakan dalam penelitian ini adalah analisis model regresi data panel. Analisis regresi panel digunakan karena data berupa gabungan dari data time series dan cross section. 
Persamaan regresi yang menunjukkan hubungan variabel-variabel independen terhadap dependen sebagai berikut:

$$
I P M=\alpha 0 i+\beta 1 \ln P A D i t+\beta 2 \operatorname{lnDAUit}+\beta 3 R \text { Eit }+\beta 4 R K i t+\text { eit }
$$

Dimana:

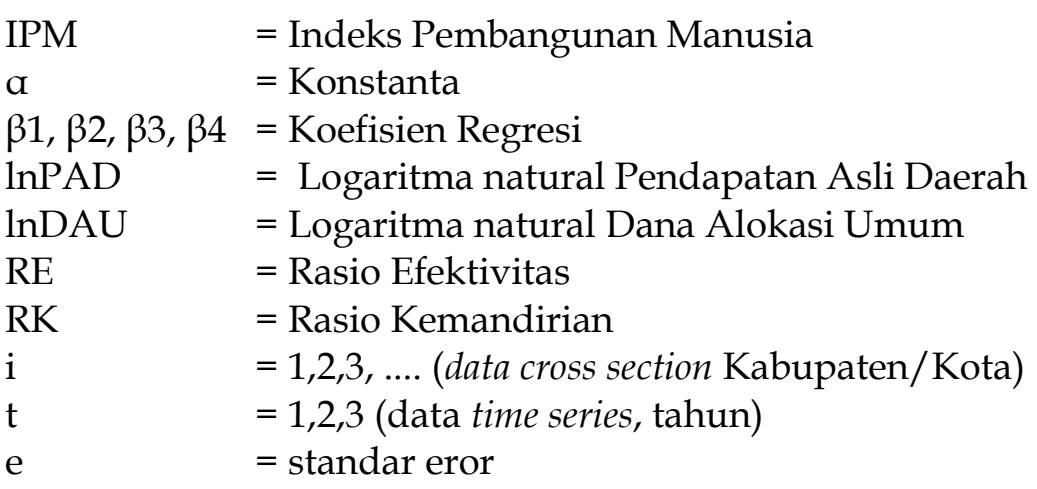

\section{HASIL DAN DISKUSI}

Uji Chow bertujuan untuk menentukan antara Common Effect Model atau Fixed Effect Model yang paling tepat dipakai untuk mengestimasi data panel. Dengan kriteria pengujian ini adalah apabila probabilitas cross section $F<0,05$ maka $\mathrm{H}_{0}$ ditolak, sehingga model yang paling tepat untuk digunakan adalah fixed effect model. Begitu pula sebaliknya.

\section{Tabel 7. Hasil Uji Chow}

Redundant Fixed Effects Tests

Equation: Untitled

Test cross-section fixed effects

\begin{tabular}{lcrc}
\hline \hline Effects Test & Statistic & d.f. & Prob. \\
\hline \hline Cross-section F & 141.711621 & $(23,44)$ & 0.0000 \\
Cross-section Chi-square & 310.932575 & 23 & 0.0000 \\
\hline \hline
\end{tabular}

Sumber: Output Eviews Statistik Versi 10

Hasil pengujian di atas menunjukkan probabilitas dari cross section $\mathrm{F}$ memiliki nilai $0,000<0,05$. Artinya $\mathrm{H}_{0}$ ditolak, sehingga fixed effect model menjadi model yang palin tepat digunakan. Dan selanjutnya dapat dilakukan pengujian Hausman agar diketahui mana model yang paling tepat digunakan antara fixed effect model atau random effect.

Pengujian Uji Hausman bertujuan untuk memilih model mana yang paling tepat digunakan antara fixed effect modal atau random effect setelah dilakukan uji chow sebelumnya. Dengan kriteria pengujian jika probabilitas cross-section random $<0,05$ maka $\mathrm{H}_{0}$ ditolak. Sehingga model yang paling tepat untuk digunakan adalah fixed effect model. Begitu pula sebaliknya. Berikut adalah hasil pengujian Hausman: 
Tabel 8.

Hasil Uji Hausman

Correlated Random Effects - Hausman Test

Equation: Untitled

Test cross-section random effects

\begin{tabular}{lrrr}
\hline \hline Test Summary & $\begin{array}{l}\text { Chi-Sq. } \\
\text { Statistic }\end{array}$ & Chi-Sq. d.f. & Prob. \\
\hline \hline Cross-section random & 88.858743 & 4 & 0.0000 \\
\hline \hline
\end{tabular}

Sumber: Output Eviews Statistik, 2019

Pengujian di atas menunjukkan nilai probabilitas cross-section random sebesar 0,000< 0,05 maka $\mathrm{H}_{0}$ ditolak dan $\mathrm{H}_{1}$ diterima. Sehingga model yang tepat untuk digunakan adalan fixed effect model. Berikut hasil pengujian regresi data panel menggunakan fixed effect model.

Tabel 9.

Hasil Uji Regresi Panel Fixed Effect Model

\begin{tabular}{crrrr}
\hline \hline Variable & Coefficient & Std. Error & t-Statistic & Prob. \\
\hline \hline C & -59.58376 & 26.11875 & -2.281264 & 0.0274 \\
X1 & 2.185339 & 0.241908 & 9.033772 & 0.0000 \\
X2 & 2.570060 & 1.099681 & 2.337095 & 0.0240 \\
X3 & 0.006413 & 0.006478 & 0.990025 & 0.3276 \\
X4 & 0.023843 & 0.019931 & 1.196244 & 0.2380 \\
\hline \hline
\end{tabular}

Cross-section fixed (dummy variables)

\begin{tabular}{llll}
\hline \hline R-squared & 0.997120 & Mean dependent var & 70.14722 \\
Adjusted R-squared & 0.995353 & S.D. dependent var & 3.665944 \\
S.E. of regression & 0.249909 & Akaike info criterion & 0.349859 \\
Sum squared resid & 2.747992 & Schwarz criterion & 1.235229 \\
Log likelihood & 15.40507 & Hannan-Quinn criter. & 0.702328 \\
F-statistic & 564.2230 & Durbin-Watson stat & 2.516489 \\
Prob(F-statistic) & 0.000000 & & \\
\hline \hline
\end{tabular}

Sumber: Output Eviews Statistik, 2019

Berdasarkan hasil analisis statistik di atas maka diperoleh rumus persamaan regresi data panel sebagai berikut:

$\mathrm{IPM}=-59.58376+2.185339 \ln \mathrm{PAD}+2.570060 \ln \mathrm{DAU}+0.006413 \mathrm{RE}+0.023843 \mathrm{RK}+\mathrm{e}$

Keterangan:

IPM : Indeks Pembangunan Manusia di Kabupaten/Kota 
lnPAD : logaritma natural Pendapatan Asli Daerah Kabupaten/Kota

lnDAU: logaritma natural Dana Alokasi Umum Kabupaten/Kota

RE : Rasio Efektivitas Kabupaten/Kota

RK : Rasio Kemandirian Kapbupaten/Kota

Uji F dilakukan untuk mengetahui apakah variabel independen yang diuji dalam model mempunyai pengaruh secara bersama-sama terhadap variabel dependen (Ghozali, 2011: 98). Berikut hasil Uji F Statistik:

Tabel 10.

Hasil Uji F Statistik

\begin{tabular}{llll}
\hline \hline R-squared & 0.997120 & Mean dependent var & 70.14722 \\
Adjusted R-squared & 0.995353 & S.D. dependent var & 3.665944 \\
S.E. of regression & 0.249909 & Akaike info criterion & 0.349859 \\
Sum squared resid & 2.747992 & Schwarz criterion & 1.235229 \\
Log likelihood & 15.40507 & Hannan-Quinn criter. & 0.702328 \\
F-statistic & 564.2230 & Durbin-Watson stat & 2.516489 \\
Prob(F-statistic) & 0.000000 & & \\
\hline \hline
\end{tabular}

Sumber: Output Eviews Statistik versi 10

Hasil pengujian di atas menunjukkan nilai $\mathrm{F}_{\text {statistik }}$ sebesar 564,223 dan probabilitas $F_{\text {statistik }}$ sebesar 0,000 . Nilai $F$ tabel berdasarkan nilai df $(4 ; 67)$ sebesar 2,51. Sehingga hasilnya $\mathrm{F}_{\text {statistik }}>\mathrm{F}_{\text {tabel }}$ yakni 564,223 $>$ 2,51, dan nilai dari probabilitasnya sebesar 0,000<0,05. Sehingga artinya seluruh variabel independen pada penelitian ini yakni PAD, DAU, Rasio Efektivitas dan Rasio Kemandirian memiliki pengaruh terhadap variabel dependen yakni IPM Kabupaten/Kota di Provinsi Jawa Tengah 2015-2017 secara simultan atau bersamasama.

Uji $\mathrm{t}$ dilakukan guna mengetahui bagaimana pengaruh secara individu variabel independen dalam menjelaskan variabel dependen (Ghozali, 2011: 98). Berikut hasil uji parsial atau uji t:

Tabel 12.

Hasil Uji -t

\begin{tabular}{crrrr}
\hline \hline Variable & Coefficient & Std. Error & t-Statistic & Prob. \\
\hline \hline C & -59.58376 & 26.11875 & -2.281264 & 0.0274 \\
X1 & 2.185339 & 0.241908 & 9.033772 & 0.0000 \\
X2 & 2.570060 & 1.099681 & 2.337095 & 0.0240 \\
X3 & 0.006413 & 0.006478 & 0.990025 & 0.3276 \\
X4 & 0.023843 & 0.019931 & 1.196244 & 0.2380 \\
\hline \hline
\end{tabular}

Sumber: Output Eviews Statistik versi 10 
Hasil pengujian statistik diatas disimpulkan sebagai berikut:

a. Pada variabel $X_{1}$ yakni PAD diketahui $t_{\text {hitung }}$ sebesar 9,034 dan probabilitas sebesar 0,000. $T_{\text {hitung }}$ dapat dibandingkan dengan $t_{\text {tabel }}$ sebesar 1,996, sehingga $t_{\text {hitung }} 9,034>$ 1,996 tabel. Dan jika dilihat dari probabilitasnya sebesar 0,000 sehingga kurang dari signifikasi 5\%, prob 0,000<0,05. Sehingga diketahui bahwa variabel $\mathrm{X}_{1}$ atau PAD memiliki pengaruh signifikan positif terhadap IPM Kabupaten/Kota di Jawa Tengah 2015-2017.

b. Pada variabel $X_{2}$ yakni Dana Alokasi Umum diketahui $t_{\text {hitung }}$ sebesar 2,337 dan nilai probabilitas 0,024. $t_{\text {tabel }}$ sebesar 1,996, sehingga $t_{\text {hitung }} 2,337>1,996 t_{\text {tabel. }}$. Dan jika dilihat dari probabilitasnya 0,024 kurang dari signifikasi 5\%, prob 0,000 $<0,05$. Sehingga diperoleh hasil Dana Alokasi Umum memiliki pengaruh signifikan positif terhadap IPM Kabupaten/Kota di Provinsi Jawa Tengah.

c. Pada variabel $\mathrm{X}_{3}$ Rasio Kefektifan diketahui $t_{\text {hitung }}$ sebesar 0.990 dan nilai probabilitas 0,3276. $t_{\text {tabel }}$ yaitu 1,996, sehingga $t_{\text {hitung }} 0,990<1,996 t_{\text {tabel. }}$. Dan jika dilihat dari probabilitasnya 0,3276 di atas nilai signifikasi 5\%, prob 0,3276>0,05. Maka diketahui Rasio Keefektifan tidak memiliki pengaruh signifikan terhadap Indeks Pembangunan Manusia.

d. Pada variabel $\mathrm{X}_{4}$ Rasio Kemandirian diketahui thitung 1,196 dan probabilitasnyar 0,238. $t_{\text {tabel }}$ sebesar 1,996, sehingga $t_{\text {hitung }} 1,196<1,996 t_{\text {tabel }}$. Dan jika dilihat dari probabilitasnya 0,238 di atas signifikasi 5\%, prob 0,3276>0,05. Maka diketahui Rasio kemandirian tidak memiliki pengaruh signifikan terhadap Indeks Pembangunan Manusia.

\section{KESIMPULAN DAN IMPLIKASI}

Berdasarkan hasil pengujian dan penelitian di atas mengenai bagaimana pengaruh Pendapatan Asli Daerah (PAD), Dana Alokasi Umum (DAU), Rasio Efektivitas, dan Rasio Kemandirian terhadap Indeks Pembangunan Manusia Kabupaten/Kota di Provinsi Jawa Tengah, maka dapat disimpulkan sebagai berikut:

a. Pendapatan Asli Daerah (PAD) berpengaruh secara signifikan positif dengan Indeks Pembangunan Manusia pada Kabupaten/Kota di Provinsi Jawa Tengah. Hal ini diketahui dari nilai $t_{\text {hitung }} 9,034>1,996 t_{\text {tabel}}$, dan probabilitasnya 0,000 kurang dari signifikansi $5 \%$. Sehingga $\mathrm{H}_{1}$ diterima. Apabila PAD semakin tinggi maka IPM Kabupaten/Kota tersebut semakin tinggi juga. 
b. Dana Alokasi Umum (DAU) memiliki pengaruh secara signifikan positif terhadap Indeks Pembangunan Manusia Kabupaten/Kota di Provinsi Jawa Tengah. Hal ini diketahui dari nilai $t_{\text {hitung }} 2,337>1,996 t_{\text {tabel }}$ dan nilai probabilitasnya 0,024 kurang dari signifikansi 5\%. Artinya apabila DAU naik, akan membuat persentasi IPM Kabupaten/Kota di Jawa tengah ikut naik. Sehingga $\mathrm{H}_{2}$ diterima. Sejalan dengan tujuan pemberian dari DAU ini yakni untuk mengurangi kesenjangan fiskal yang juga dapat berdampak pada pelayanan terhadap masyarakat daerah tersebut sehingga dapat meningkatkan indeks pembnagunan manusia.

c. Rasio Efektivitas tidak memiliki pengaruh secara signifikan terhadap indeks pembangunan manusia pada Kabupaten/Kota di Provinsi Jawa Tengah tahun 20152017. Hal ini diketahui dari nilai thitung 0,990< 1,996 ttabel. Dan jika dilihat dari probabilitasnya 0,3276 di atas nilai signifikansi 5\%. Maka $\mathrm{H}_{3}$ tidak dapat diterima. Hal ini kurang sesuai dengan teori yang ada namun juga bisa dimungkinkan bahwa Pemerintah Daerah Kabupaten/Kota di Jawa Tengah telah mencoba menaikkan tarif pajak daerah untuk meningkatkan pendapatan asli daerah namun hal tersebut tidak dibarengi dengan pemberian fasilitas pendidikan, kesehatan dan ekonomi terhadap masyarakat yang meningkat pula.

d. Rasio Kemandirian tidak memiliki pengaruh signifikan terhadap indeks pembangunan manusia pada Kabupaten/Kota di Provinsi jawa Tengah tahun 20152017. Hal ini diketahui dari nilai $t_{\text {hitung }} 1,196<1,996 t_{\text {tabel. }}$. Dan jika dilihat dari probabilitasnya sebesar 0,238 di atas nilai signifikasi 5\%. Sehingga $\mathrm{H}_{4}$ ditolak. Meskipun kurang sesuai dengan teori, namun hal ini bisa dikarenakan dari 24 sampel yang digunakan hampir semua nilainya berada dibawah 30\% yang artinya berada pada level rendah sekali dan rendah, hanya Kota Semarang yang memiliki persentasi rasio kemandirian di atas $60 \%$ yang artinya berada pada level sedang.

\section{REFERENSI}

Anggraini, T. (2015). Pengaruh Rasio Keuangan Pemerintah Daerah terhadap Indeks Pembangunan Manusia Pemerintah Provinsi di Indonesia. (Disertasi. Universitas Sebelas Maret, Surakarta)

Badan Pusat Statistik (2014). Booklet Indeks Pembangunan Manusia Metode Baru, Badan Pusat Statistik. Provinsi Jawa Tengah.

Dwindra. (2008). Efektivitas dan Kemandirian Keuangan Daerah Otonom Kabupaten/Kota di Provinsi bali Tahun 2002-2006. Jurnal Akuntansi Bisnis Vol. III, No.2 
Dwiyandari, dkk. (2018). Pengaruh kinerja keuangan pada belanja daerah dan pertumbuhan ekonomi dan implikasinya pada indeks pembangunan manusia. E-Jurnal Akuntansi Universitas Udayana. Vol 22 No. 3.

Ghozali, I. (2011). Aplikasi analisis multivariat dengan program IBM SPSS 19. Cet, ke-lima. Semarang: Badan Penerbit Universitas Diponegoro.

Halim, Abdul. (2002). Bunga Rampai: Manajemen keuangan daerah. Edisi I. Yogyakarta: UPP AMP YKPN

Halim, Abdul. (2007). Akuntansi Sektor Publik: Akuntansi Keuangan Daerah. Jakarta : Salemba Empat.

Indriantoro, N dan Supomo, B. (2002). Metodologi Penelitian Bisnis Untuk Akuntansi $\mathcal{E}$ Manajemen. Cet. Ke-dua. Yogyakarta: BPFE Yogyakarta

Rahmawati, Farida. (2008). Desentralisasi Ekonomi. Dalam Ahmad Erani Yustika (Editor), Desentrlasisasi Ekonomi di Indonesia: Kajian Teoritis dan Realitas Empiris. Edisi I, Cet ke-1. Malang: Bayumedia Publishing.

Sarkoro, Hastu \& Zulfikar. (2016). “Dana alokasi khusus dan pendapatan asli daerah terhadap indeks pembangunan manusia". Riset Akuntansi dan Keuangan Indonesia, Vol 1, No 1

Suryaningsih, Ni Nyoman, Made Suyana Utama, \& LN Mahendra Yasa. (2015). “Dampak kinerja keuangan daerah terhadap kesejahteraan masyarakat Kabupaten/Kota di Provinsi Bali". E-Jurnal Ekonomi dan Bisnis Universitas Udayana Vol. 4, No. 8.

Undang-Undang No 32 Tahun 2004 tentang Pemerintahan Daerah.

Undang-Undang No 33 Tahun 2004 tentang Perimbangan Keuangan antara Pemerintah Pusat dan Daerah.

UNDP. (2018). Human Development Indices and Indicators 2018 Statistical Update. Diunduh dari http://hdr.undp.org/en/2018-update/download tanggal 3 Maret 2019 